ISSN: 2224-0616

Int. J. Agril. Res. Innov. \& Tech. 6 (1): 41-46, J une, 2016

Available online at http:// www.ijarit.webs.com

\title{
THE ROLE OF SHORT ROTATION COPPICE TECHNOLOGY IN FUELWOOD SUPPLY IN RUNGWE DISTRICT, TANZANIA
}

\author{
G.M. Karwani ${ }^{*}{ }^{*}$ L.L.L. Lulandala ${ }^{2}$, A. Kimaro ${ }^{3}$ and Z.P. Msigwa ${ }^{4}$ \\ Received 29 March 2016, Revised 10 June 2016, Accepted 21 June 2016, Published online 30 June 2016
}

\begin{abstract}
The roles of Short Rotation Coppice (SRC) Technology in fuelwood supply and offsetting $\mathrm{CO}_{2}$ emissions in the Tanzania and most African countries remain poorly understood. This study was carried in Rungwe District, Mbeya region in Tanzania, to determine trends, extent and drivers of adoption of SRC; identify various sources of household energy and assess the contribution of SRC to the total household fuelwood needs, and trees and shrub species used as sources of fuelwood. Data were collected using reconnaissance, field and social surveys and was analyzed using the Statistical Package for Social Sciences (SPSS). Results revealed that, $97.5 \%$ of local community adopted the SRC technology since 1960s. Eucalyptus spp. are mostly planted in woodlots and field boundaries while Persea americana and Leucaena leucocephala are intercropped in farmlands. The survey indicated that out of 176 tons of fuelwood used annually, 73\% comes from SRC technology, 25\% from non-SRC technology, and only $2 \%$ is purchased to supplement household fuelwood shortage. Local communities depend heavily on biomass energy from woodlots and farmlands where tree species like Eucalyptus spp. plays a key role in meeting the energy demand. This study demonstrates that SRC technologies like woodlots, boundary planting, and intercropping in farmland hold high promise to meet the household energy demand. If promoted and backed with strong policies and supportive land tenure, these technologies may reduce the harvesting pressure on native forests for energy demand and contribute to climate change mitigation and adaptation.
\end{abstract}

Keywords: Bioenergy, Boundary Planting, Tanzania, Woodlots

\footnotetext{
${ }^{1}$ Maruku Agriculture Research Institute, P. O. Box, 127 Kagera, Tanzania

${ }^{2}$ Sokoine University of Agriculture, P. O. Box 3000, Morogoro, Tanzania

${ }^{3}$ World Agroforestry Centre, P. O. Box 6226, Dares Salaam, Tanzania

${ }^{4}$ Agriculture Officer, Bukoba District Council, P.O. Box 127, Bukoba, Kagera, Tanzania

*Corresponding author's email: nachimbugwe@yahoo.com (G.M. Karwani)
}

\section{Introduction}

Most of households' especially rural areas in Tanzania rely on wood fuel to meet their energy needs. According to the current trends, it estimated that, about $90 \%$ of the Tanzanian population depends on traditional biomass, $7 \%$ account for fossil fuels and other sources account for 3\% (URT, 2003), wood fuel plays as a key main source of energy to both urban and rural areas, and will continue to be an important source of energy in the coming decades (Sawe, 2008). The highly dependence of wood fuel from natural forest for energy uses by households result into forest areas are being harvested at a rate faster than the regeneration rate of forests. Deforestation has estimated at $0.97 \%$ or $4,03,350$ ha per annum between 1990 and 2010 (FAO, 2010). Tanzania lost $19.4 \%$ of its forest cover or around $80,67,000$ ha during that period (FAO, 2010).

In Rungwe district, the rate of deforestation and extent of households depend on energy from natural forest has been reduced since SRC technology started in 1960's (FAO, 2009). This technology has been contributing much to woodfuel needs to households. The common tree species planted from SRC technology in the farmlands and woodlots are Eucalyptus spp and Persea americana. The Short Rotation Coppice (SRC) technology is very common practice in Rungwe, Tanzania whereby households planting woody vegetation and grown on a repeated coppice cycle of 3-6 years specifically for the production of biomass. The area has been identified as a one of the greatest potentials for biomass production for energy in the Tanzania (Hoogwijk et al., 2005). Coppicing is a traditional method of woodland, which takes advantage of the fact that many trees reshoot from the stump or roots if cut down. The SRC technology has been done in the district by planting different trees species, The common trees species planted by households in their farmlands and woodlots are Eucayptus spp., Persea americana, Grevillea robusta, Leucaena leucocephala Cedrella mexicana and Ficus natalensis. 
The use of SRC trees in farmlands and woodlots offers options for enhancing the resistance and resilience to environmental change while at the same time satisfying the demand for wood fuel (Heller et al., 2003; Volk et al., 2004). In addition to that, the implementation of SRC tree species provide effective alternative source of income and energy for small-scale farmers in rural areas (Volk et al., 2004).

In Rungwe district there have been campaigns to emphasized the households to plant trees every year by using SRC technologies like woodlots, mixed intercropping and field boundary for meeting energy needs since 1960s (URT, 2003). Since promoted, the SRC play great role in wood fuel supply to households, However the reports on the extent of SRC contribution to energy uses to households in Rungwe District is scarce. Also the reports on which tree species more preferred and SRC technology practiced and contribute more wood fuel to households is rare (URT, 2003). The study aimed to determine trends, extent and drivers of adoption of SRC; identify various sources of household energy and assess the contribution of SRC to the total household fuelwood needs and trees species used as sources of fuelwood.

\section{Methodology}

\section{Description of the study area}

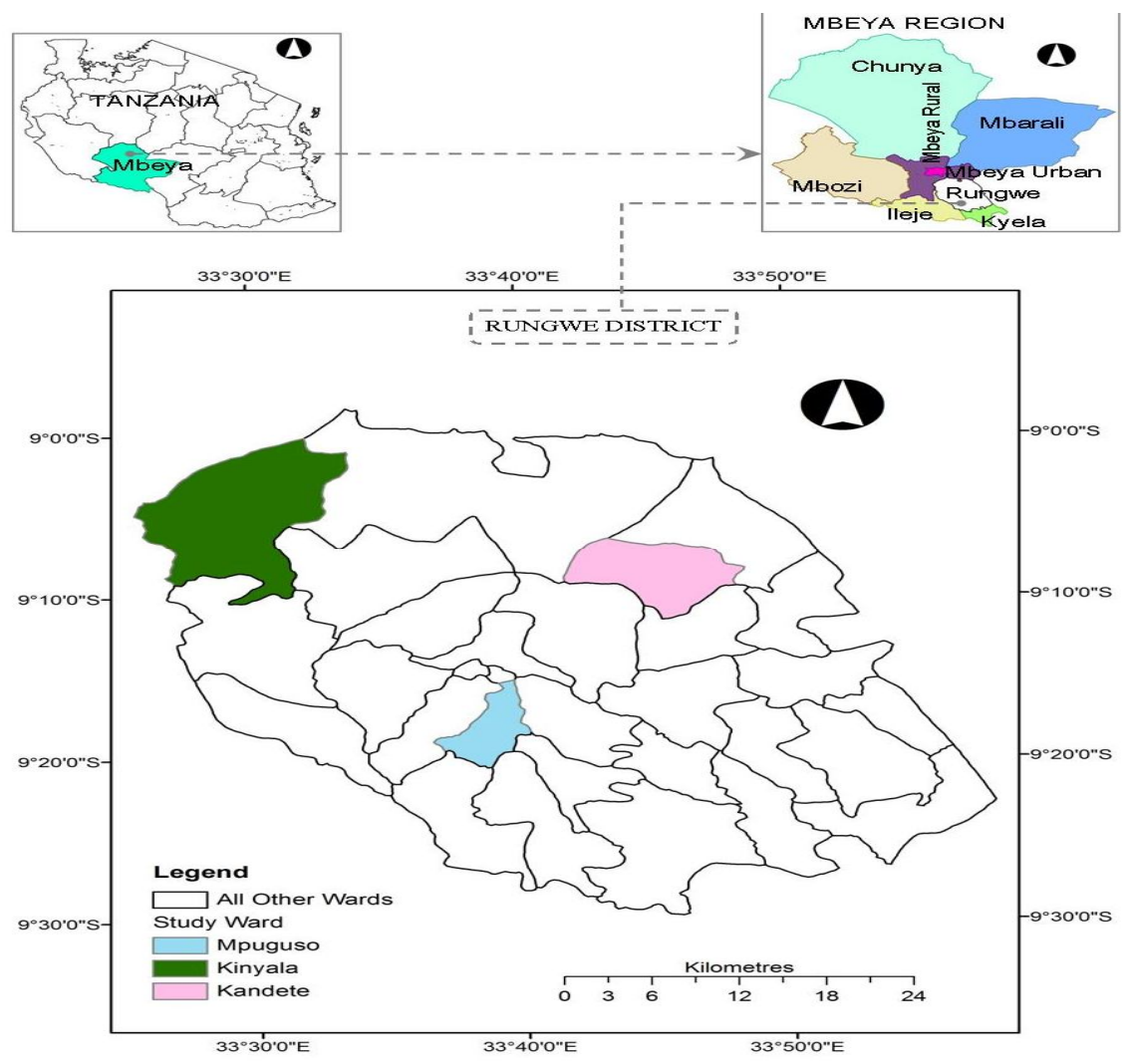

Fig. 1. Map showing location of the study wards of Rungwe district, Source: URT (2009)
The study was conducted in Rungwe district Mbeye, Tanzania in three wards namely Kandete (Ndala Village), Kinyala (Isumba Village) and Mpuguso (Mibura Village). The district located between latitudes 9o $00^{\prime}$ and $9^{\circ} 30^{\prime} \mathrm{E}$ and longitudes $33^{\circ}$ and $34^{\circ} \mathrm{S}$ with total area covered about $2221 \mathrm{~km}^{2}$ (Fig. 1). The elevation ranges from $770 \mathrm{~m}$ a.s.l to $2265 \mathrm{~m}$ a.s.l, with higher elevation predominating.

The area characterized by mountainous of Rungwe and the Livingstone with an altitude of $770 \mathrm{~m}$ to $2265 \mathrm{~m}$ above sea level. These mountains have great influence on the climatic condition of the district and make it experience cold and rainy seasons. Average rainfall ranges from $900 \mathrm{~mm}$ in the lowland areas to $2700 \mathrm{~mm}$ on the highlands. Temperatures are generally modest and range from $18^{\circ}-25^{\circ} \mathrm{C}$ all the year round.The district shares borders with Kyela District in the South, Ileje District in the West, Makete District (Iringa Region) in the East and Mbeya District in the North (URT, 2003). The selection of the study area was based on the fact that the district is one of the major producers of tea in the country and had been implementing SRC technology to supply fuelwood to the tea curing industries and for household consumption (URT, 2009). 


\section{Sampling procedure and sample size}

Multi-stage sampling procedure was used in drawing the samples in which there was a random selection of group's stage-wise from villages, and households. The district has four divisions; one division is located in town. All of the three rural divisions were selected and from each division one ward was randomly selected. In each selected ward one village also was selected randomly from the list of all villages in a ward. Forty households were randomly selected from village register books to constitute the sampling units that make a total of 120 sample households. A random sampling technique was preferred in order to avoid bias and provide equal opportunity for each household to be included in the sample size and provide essential information at low cost than complete enumeration.

\section{Data collection}

Both primary and secondary data were collected. Primary data collection was carried out through reconnaissance, field and social/household surveys.

Reconnaissance survey was conducted in order to familiarize with the study area, ascertain sampling process and to help in improvement of the study plans, explain objectives of the study to various administrative levels. More a reconnaissance survey was done to get a general picture of the study area and pre-test the questionnaire. Pre testing of the questionnaire was done in order to check its validity and reliability. It also helped in identification of relevant partners in villages from whom to acquire various data. Data included extent of adoption of SRC technology, various sources of energy, non and SRC trees and shrubs found in the district and quantification of fuel wood from the SRC technology.

\section{Field survey}

Through field survey, quantification measurements were carried out using a portable mass balance and tape measure for determination of weight and volume respectively of fuelwood's head load, piles diameter and height. Transect walk was conducted in order to determine the type of SRC technology practiced and tree species in each household surveyed/interviewed.

\section{Social survey}

This was conducted using Focused Group Discussions (FGDs), questionnaire survey and a checklist of probe questions.

(i) Focused Group Discussions
Leading questions relevant to SRC trees and shrubs for fuelwood was used to guide focused group discussions. The FGD was conducted in each village and included local government leaders, influential trees growers, Wakulima Tea Company/factory managers and extension officers. Participants of focused group discussion was selected based on their time convenience and were briefly interviewed to qualify for group discussion. The discussion with key informants was focused on the role of SRC technology in fuel wood supply. An attempt was also made to revisit unpublished literature and reports in the district's council relevant to subject matter.

\section{(ii) Questionnaire}

The sampling frame was village registers and sampling units was head of household, which was randomly selected from the village registers. Semi structured questionnaire with both open and closed-ended questions was used as a tool to interview the household's head.

\section{Secondary data}

Secondary data was obtained from Natural resource office of Rungwe District Council, on line databases and Sokoine National Agricultural Library (SNAL).

\section{Data processing and analysis}

Primary data collected was reedited and coded to facilitate data entry, statistical analysis and summarized into means and percentages in tables and figures. Analysis of Variance (ANOVA) was used to determine whether there were significant differences between parameters studied by the aid of Statistical Package for Social Science (SPSS) 16.0 version computer programmes using CRBD analytical model. The F-test was used to determine the existence of differences between the variable means and the Least Significant Difference (LSD) was used for segregating the differing means.

\section{Results}

\section{Various sources of energy in Rungwe district}

The communities in Rungwe district depend widely on firewood $(40 \%)(n=40)$ as a primary source of energy for domestic uses, followed by kerosene $(30.3 \%)(n=40)$, charcoal $(9.3 \%)$, biogas (2.67) $(n=40)$, solar energy $(0.67 \%)(n=40)$ and electricity (0.33) $(n=40)$ (Fig. 2). The main uses of fuelwood at household is cooking and heating. Large quantity of firewood was obtained from woodlots, mixed intercropping and field boundary. These technologies also offer wood for timber, income generation and building poles. 


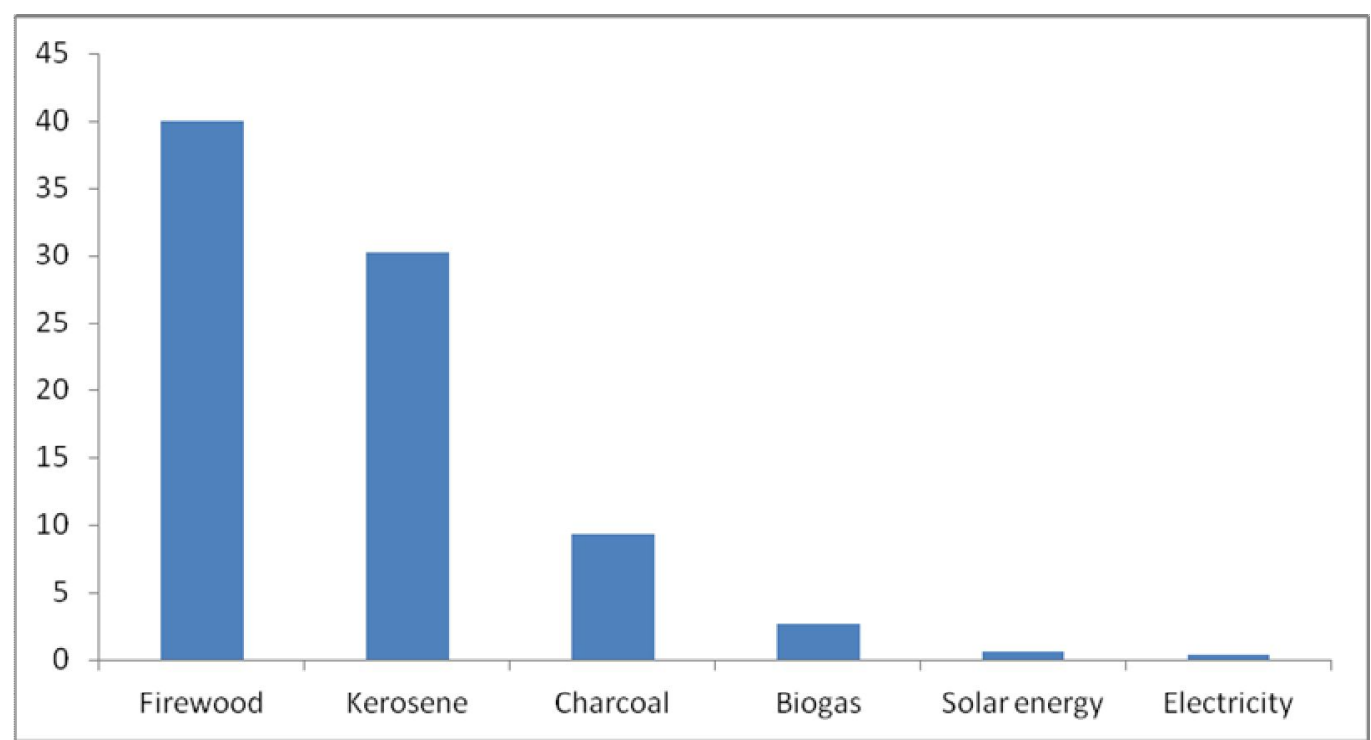

Fig. 2. Various sources of energy in Rungwe district

\section{Contribution of SRC technology to the household fuel wood consumption needs}

SRC technology had potential to households for wood fuel supply, due to the fact that, the total fuel wood consumed by households in all three wards was 176 tonnes year ${ }^{1}$ whereby, 73 $\%(n=126)$, had been sourced from the SRC technology and $25 \%(\mathrm{n}=126)$ from non SRC technology. Only $2 \%(n=120)$ of tonnes year ${ }^{-1}$ of fuelwood were bought by the households in Rungwe (Fig 3).

Furthermore the monthly consumption of wood fuel from SRC technology within the family indicated that, $79.8 \%$ of the family size range between 4-6 people consume about 61- $183 \mathrm{~kg}$ of fuelwood per month, equivalent to 2.2 tonnes consumed annually, also $10.8 \%$ live in the family size of about 1-3 people and consumed about 61$175 \mathrm{~kg}$ per month and 2.1 tonnes year ${ }^{1}$ of fuelwood. Furthermore the family size of about 710 people which constitute $10 \%$ consumed about $84-214 \mathrm{~kg}$ per month of fuelwood, that means that they consume about 2.5 tonnes year ${ }^{1}$ in maximum and about $7 \mathrm{~kg}$ consumed daily.

The most tree species consumed are Eucalyptus spp. and Persea spp. The higher preferences of these species by respondents in the study area were attributed to fast and vigorous growth even in poor soils, capacity to sprout or coppice when subjected to cutting or burning and production of diverse of marketable products firewood, timber, fruits

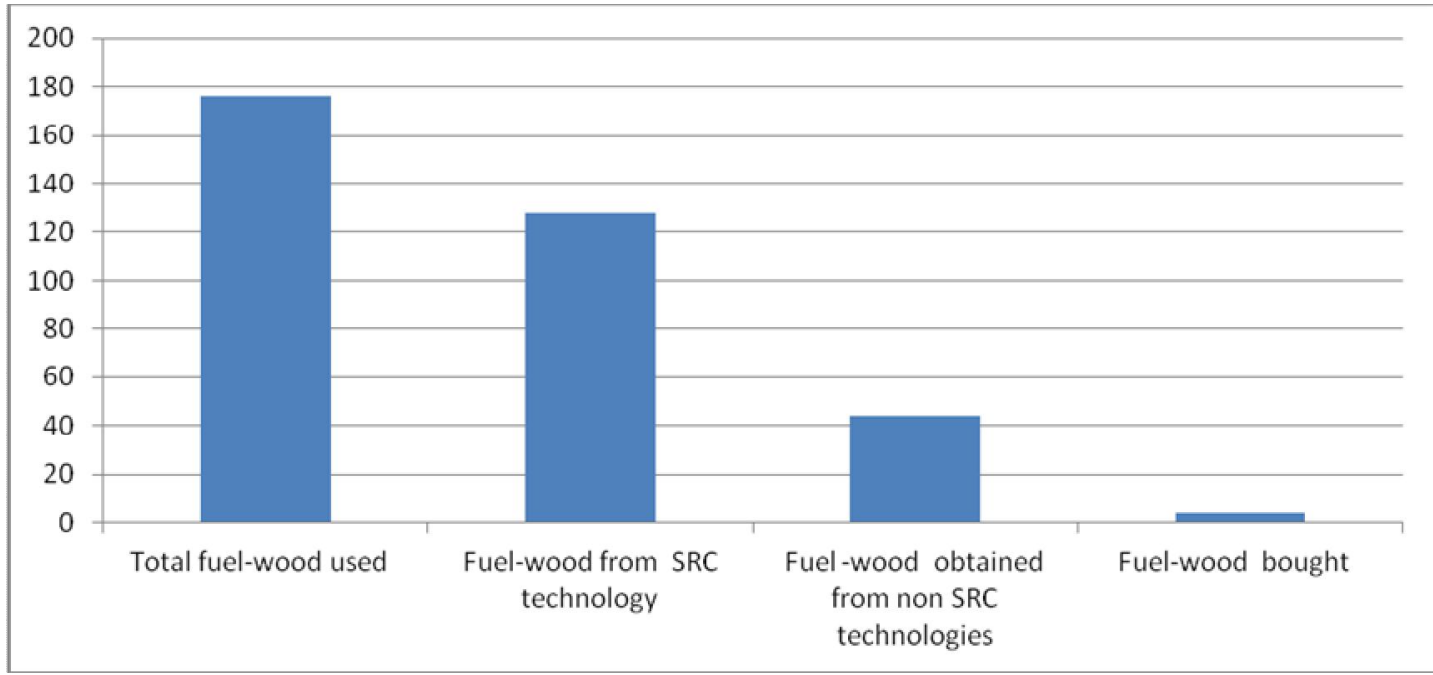

Fig. 3. The consumption of fuel-wood in tonnes per year by the communities in Rungwe district 


\section{The SRC practices adopted by the local Communities in Rungwe district}

The households in Rungwe district planted the trees by using SRC technologies of wood lot, mixed intercropping and field boundary with average of $38.6 \%, 32.2 \%$ and $29.2 \%$, respectively (Table 1).

The most practiced technology is wood lot probably due to the most communities member planted Eucalyptus spp. as source of fuelwood, which is obvious, not intercropped with other food crops. The lower level of field boundary practices which in average of $29.2 \%$ in the area, mainly results from the limited tradition in animal husbandly production by the local communities and the livestock. The domination of woodlot practice mainly composed of the exotic wood perennial species such as Eucalyptus in all the three villages found in Rungwe district

Table 1. The SRC practices adopted by the local Communities in Rungwe district

\begin{tabular}{lc}
\hline SRC Practice & Percentage \\
\hline Woodlot & $38 \mathrm{a}$ \\
Mixed intercropping & $62 \mathrm{~b}$ \\
Field boundary & \\
Total & $\mathbf{1 0 0}$ \\
\hline
\end{tabular}

The values in the same column that are followed by the same letter do not differ significantly at $\mathrm{p} \leq 0.05 . \mathrm{LSD} 0.05=25.46$

\section{Discussion}

Wood fuel from SRC technology have been source of energies to the households in Rungwe district. Households in the district depends on bioenergy derived from SRC technology. The high dependence of wood fuel have attributed by social-economic and environmental factors, social factor such as energy demand drives people to practice SRC technology on which more wood fuel used for domestic purpose like cooking and heating. According to Extension officer SRC technology offer the best option for firewood and charcoal production to households for energy use. In addition to that SRC technology contributes to change of livelihoods by generating income of local people through supply wood fuel to local industry found in the district. Local people supply more wood fuel and earn money after selling them to Tea industry, the company managers stated that, the currently demands reached over $23,000 \mathrm{~m}^{3}$ of firewood per annum (over 18,000 $\mathrm{m}^{3}$ at Katumba and 5,000 $\mathrm{m}^{3}$ at Mwakaleli respectively. Furthermore, FAO (2009) reported that WATCO takes $1 \mathrm{~m}^{3}$ or 0.65 tons of dry wood to cure $350 \mathrm{~kg}$ of tea. The smallholder farmers contribute much to the supply of fuelwood, which reached about $80 \%$ of the entire supply. Education on proper selection SRC species that the use of proper SRC species, and proper arrangement is essential in order to avoid negative effects like competition for resources like, light, water and nutrients such as pruning, pollarding where necessary (Chirwa et al., 2003).

The use of SRC technologies also offer environments benefits, because trees on farms play a great function like a natural fertilizer by fixing nitrogen in the soil and make microclimate (Ramadhan et al., 2002), which increases crop yields. Despite yields can be maximized by using smart combinations of trees and agricultural crops, but suitable selection of tree species and SRC plantations has much influence on crops yields (Chileshe and Kitalyi, 2002). Sustainably managed of SRC on farmlands or any area provides a source of renewable energy with virtually no net carbon emissions i.e. no increase in atmospheric carbon (Upham, 2009). Thus, stems are usually harvested from SRC plantations in every 3-5 years, coppice stools remain productive for up to 30 years before they require replacing and coppice stems are usually cut and chipped (Buchholz et al., 2009). Planting SRC in place of conventional agricultural crops increases farm diversification and reduces chemical input. Additionally, the plantations form an interesting alternative landscape and habitat type for wildlife.

\section{Conclusion}

It concluded that, SRC technology play great role on wood fuel supply to households in Rungwe district, this is because $85 \%$ respondents in the study area responded that, depend more on energies from SRC technology than non SRC technology. The use of this technology it contributed much energy to households as well as helped to protect the environment. This is because people rely more energy from SRC rather than from non SRC like natural forests.

It is recommended that, although SRC technologies have been practiced to large extent by the households in Rungwe district and having 
impact in their livelihoods. However, the most adopted SRC tree species are Eucalyptus, therefore more research is required to establish other SRC tree and shrub species in the District. In addition, more intervention like bio energy crops such as Jatropha curcus, Palm among others should be done in order to overcome the problems of energy supply in the district.

\section{References}

Buchholz, T., Luzadis, V. A. and Volk, T. A. 2009. Sustainability criteria for bioenergy systems: Results from an expert survey. J. Cleaner Prod. 17(1): 86-98.

Chileshe, E.C. and Kitalyi, A. 2002. Management of Rangelands. Regional Land Management Unit, ICRAF House, Gigiri. Nairobi, Kenya. p. 10.

Chirwa, T.S., Mafongoya, P.L. and Chitu, K. 2003. Mixed planted fallow using coppicing and non-coppicing trees for degraded acrisols in Eastern Zambia. J. Agroforestry Systems 59(3): 243- 251.

FAO. 2009. Criteria and Indicators for Sustainable Wood Fuels: Case Studies from Brazil, Guyana, Nepal, Philippines and Tanzania. Food and Agriculture Organization, Geneva, Switzerland. 178p.

FAO. 2010. Global forest resources assessment: country report, United Republic of Tanzania. [http:// www.fao.org/ forestry/fra.htm] site visited on 25/8/2010.

Heller, M.C., Keoleian, G.A. and Volk, T.A. 2003. Life cycle assessment of a willow bioenergy cropping system. Biomass \& Bioenergy 25: 147-165.

Hoogwijk, M., Faaij, A.X.E., Eickhout, B., de Vries, B. and Turkenburg, W. 2005. Potential of biomass energy out to 2100, for four IPCC SRES land-use scenarios. Biomass \& Bioenergy 29(4): 225 - 257.

Ramadhan T., Otsyna, R. and Franzel, S. 2002. Improving household incomes and reduce deforestation using rotation woodlots in Tabora District, Tanzania. Agric. Ecosys. Env. 89: 229-239.

Sawe, E.N. 2008. Bioenergy policy in Tanzania. pp. 13-14. In: Complete International Workshop on Bioenergy Policies for Sustainable Development in Africa. $\left(\mathrm{Ed}^{\mathrm{n}}\right.$ Edineba, S. et al.), 25-28 November 2008, Bamako, Mali.

Upham, P. 2009. Applying environmentalbehaviour concepts to renewable energy siting controversy: Reflections on a longitudinal bioenergy case study. J. Energy Policy 37(11): 4273-4283.

URT, 2003. The Socio- Economic Profile Mbeya Region. National Bureau of Statistics, Dar es Salaam, Tanzania. 270p.

URT, 2009. The Socio- Economic Profile Mbeya Region. National Bureau of Statistics, Dar es Salaam, Tanzania. 195p.

Volk, T.A., Verwijst, T., Tharakan, P.J. and Abrahamson, L.P. 2004. Growing energy: assessing the sustainability of willow shortrotation woody crops. Frontiers in Ecol. Env. 2(8): 411-418. 